\title{
Car scrappage incentives policies: a life cycle study on GHG emissions
}

\author{
M. Lelli, G. Pede, M. P. Valentini \& P. Masoni \\ ENEA, Italy
}

\begin{abstract}
In the last decade a certain number of car scrappage incentives programs have been promulgated to promote earlier replacement of aging vehicles with new ones, cleaner and more efficient, with the aim of pollutant emission reduction and transport safety improvement. Some concerns have been raised about the effectiveness and efficiency of those measures, in particular in relation to the overall environmental impacts along the life of the vehicle phases - production, use, end of life - and fuel life chain.

This life cycle study is focused on the effects on greenhouse gases emissions of a car scrappage scheme in a time range of 24 years, from 1996 to 2020, reducing the average vehicle life from 12 to 10 years; the reference value of retirement age is calculated from the Italian vehicle fleet and used cars market statistics.

Two case studies are analyzed for two reference gasoline cars and one diesel car, representative of the European and USA fleet in 2005, considering emissions and consumption data respectively from the MIT and JRC reports published in 2008. In the baseline case it is considered the expected technological evolution of conventional gasoline vehicle both on propulsion and non-propulsion systems. The advanced case takes into account a higher technology improvement up to 2020, with hybrid propulsion systems.

Both case studies show that the GHG emissions on the whole vehicle life cycle are neutral with respect to car replacement acceleration, provided that the promoting incentives are restricted to the more energy efficient new vehicles, and new technologies development expected for 2020 will be achieved.
\end{abstract}

Keywords: GHG emissions, life cycle analysis, car scrappage, passenger cars. 


\section{Introduction}

Since the 1990s European and North American governments have adopted policies of scrappage subsidies in order to stimulate the early voluntary removal of used cars. Such grants may be used as a policy tool to reduce overall pollutant emissions from passenger cars by retiring the oldest vehicles, with the worst emission standards or no standard at all. Within the European Union, France, Greece, Hungary, Ireland, Italy, and Spain offered subsidies that required purchasing a new vehicle as a replacement. Instead, Denmark and Norway, similarly to the United States and Canada, offered subsidies just for scrapping old vehicles [1-3].

The scrappage incentives adopted in Italy in the last two years required the replacement of the old cars with new ones respecting standards even for greenhouse gas emissions. On the whole, those policies have been successful in increasing the rate of vehicle fleet replacement, diminishing national pollutant emissions.

A potential environmental trade-off of measures related to the reduction of the average life of a car, is the corresponding increasing rate of natural resources use, like materials and energy use in car manufacture and waste. This is the reason why in the last ten years different national and international research institutes have investigated the environmental effects of the scrappage policies from a life cycle point of view, under specific hypothesis of vehicles technical improvements in specific regional patterns.

The purpose of this study is to estimate the potential future impacts on GHG emissions of a scrappage scheme for passenger cars in 24 years, from 1996 to 2020 , considering the technology evolution on the basis of the studies in literature.

The most recent and complete applications of Life Cycle Assessment (LCA) for the transport sector are presented briefly in Section 2. Section 3 illustrates methodology, assumptions and input data used in the present study. Finally, in Section 4 , the results and conclusion are reported.

\section{Life cycle analysis: literature review}

The life cycle approach in assessing impacts associated with a product or service is a method that includes all the stages of a product system, from the extraction of raw materials, through the production of materials and intermediates, the product use or the service operation, to recycling and final disposal. In this way, the estimated impacts are prevented to be associated to wrong phases, helping policy makers, industry and all the stakeholders to improve or modify the product process and use in a way of reducing the more impacting phases.

Different life cycle applications were developed for addressing various life cycle-generated impacts and possible measures to minimize them: LCA, Life Cycle Management (LCM), Life Cycle Costing (LCC), etc. Some examples of those applications are: product development and improvement, process and 
service operation, strategic planning, technological impact assessment, public policy making, marketing [4].

For vehicles LCA, the following five processes have to be taken into account (Figure 1):

- car production: raw material extraction, material transformation and car assembly;

- replacement and spare parts production (tyres, battery, lubricants and refrigerants)

- car disposal and waste treatment (end-of-life - EOL);

- fuel transformation process upstream to fuel consumption (well-to-tank WTT), composed of primary energy extraction, fuel production and distribution;

- vehicle use (tank-to-wheel - TTW).

In this study the first three processes are considered in one stage, called Materials; the WTT and TTW phases together represent the complete energy conversion chain, the so called well-to-wheel (WTW) $[5,6]$.

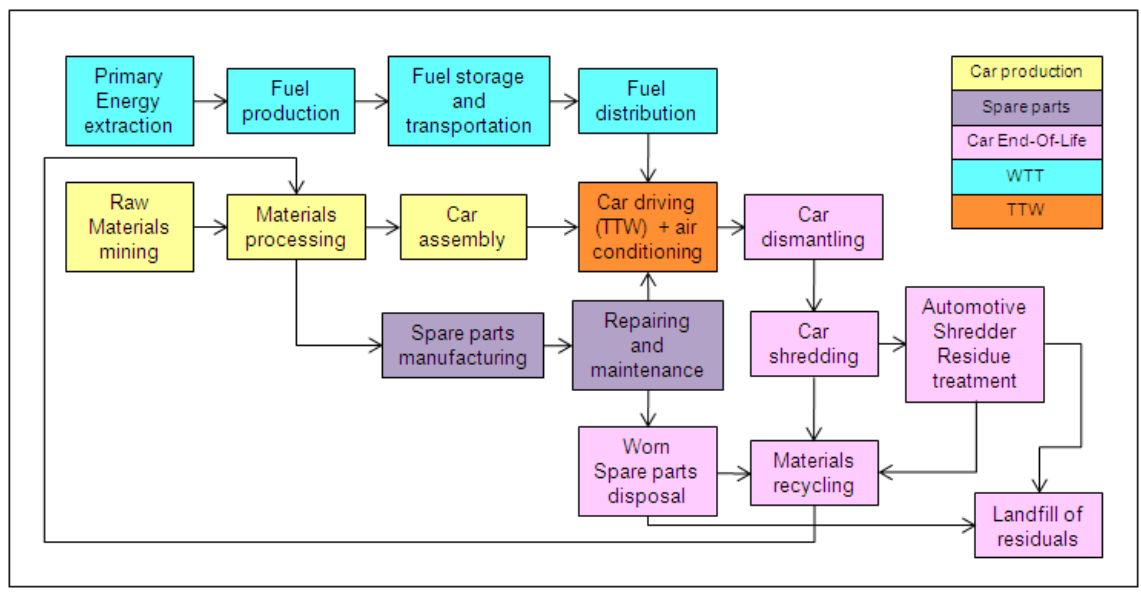

Figure 1: $\quad$ Car life cycle diagram.

The MIT studies were the first at focusing on the impacts of vehicle production and end-of-life [7]. In the 2008 a report commissioned by the European Commission was published by JRC with an extensive LCA study of current European passenger cars and forecast of vehicle technologies and alternative fuels evolution [6].

\subsection{The MIT analysis}

The objective of the MIT study was to assess and compare the potential reduction of fuel consumption and GHG emissions deriving from the evolution of light-duty vehicles technologies during the next 25 years, from a life cycle prospective. 
Fuel consumption and GHG emissions of an average car, both currently and in the future, were quantified for a combination of the more implemented/promising technologies. All considered vehicles have the same performance and size; weight, battery and fuel cell type are those representative in 2005; as a matter of fact, MIT assumed that any weight reduction for future vehicles is realized using lightweight materials, that are more energy intensive than steel; similarly, the use of energy intensive materials for components such as batteries and fuel cell membranes in hybrid and fuel cell vehicles (FCVs), is expected to increase energy consumption and GHG emissions.

Consumption and emissions of different propulsion technologies in the vehicle use stage (TTW) were calculated with simulations over several standard driving cycles. The size and performance of future vehicles was set constant at the level of the Toyota Camry, with a 2.5-liter engine, used as a representative car. Scaling laws were used to estimate the evolution of individual vehicle components of the future vehicle. For the non-propulsion systems, the improvement in vehicle aerodynamics and tire rolling friction is assumed to hold a constant annual rate of reduction respectively of $1 \%$ and $1.65 \%$. A $20 \%$ reduction in curb weight was assumed for all the future gasoline engine vehicles at constant size and safety. Reduction in vehicle size and weight can significantly reduce fuel consumption. Every $10 \%$ of weight reduced from the average new car can cut fuel consumption by around $7 \%$. For the propulsion system, transmission improvements coupled with improvements in bearings, gear sealing elements, as well as hydraulics, can increase the efficiency of transmissions from around $89 \%$ today to $94 \%$ in the future. The future Naturally Aspirated SparkIgnition (NA-SI) engines were projected by extrapolating historical trends which have demonstrated improvements on the order of $0.5 \%$ per year.

The gasoline hybrid (HEVs) model is configured as a single-motor parallel hybrid, with a hybridization ratio of $25 \%$, sufficient to fulfill most of the vehicle's regenerative braking requirement under the USA's "typical" driving conditions. For the future HEV model, it was assumed that battery specific energy improves at a rate of about $2 \%$ per year.

For the fuel chain (WTT), the conventional gasoline production was considered equal to $24 \mathrm{MJ} / \mathrm{MJ}$ delivered in tank, with no efficiency improvements until 2035.

Figure 2 shows the MIT results for the GHG emissions for the three LC stages - WTT, TTW and Materials - for the average gasoline Spark-Ignition Engine vehicles (SIE) in 2005 and projected to 2035. Plug-in hybrid with 30miles all electric range (PHEV-30), Hydrogen Fuel Cell Vehicle (FCV) and Battery Electric Vehicle (BEV) are also considered, denoting the uncertainty about the WTT GHG emissions for electricity generated from coal (upper bound) and natural gas (lower bound). All 2035 vehicles were supposed to have more efficient transmissions, $20 \%$ lower weight and reduced drag and tire resistances. 


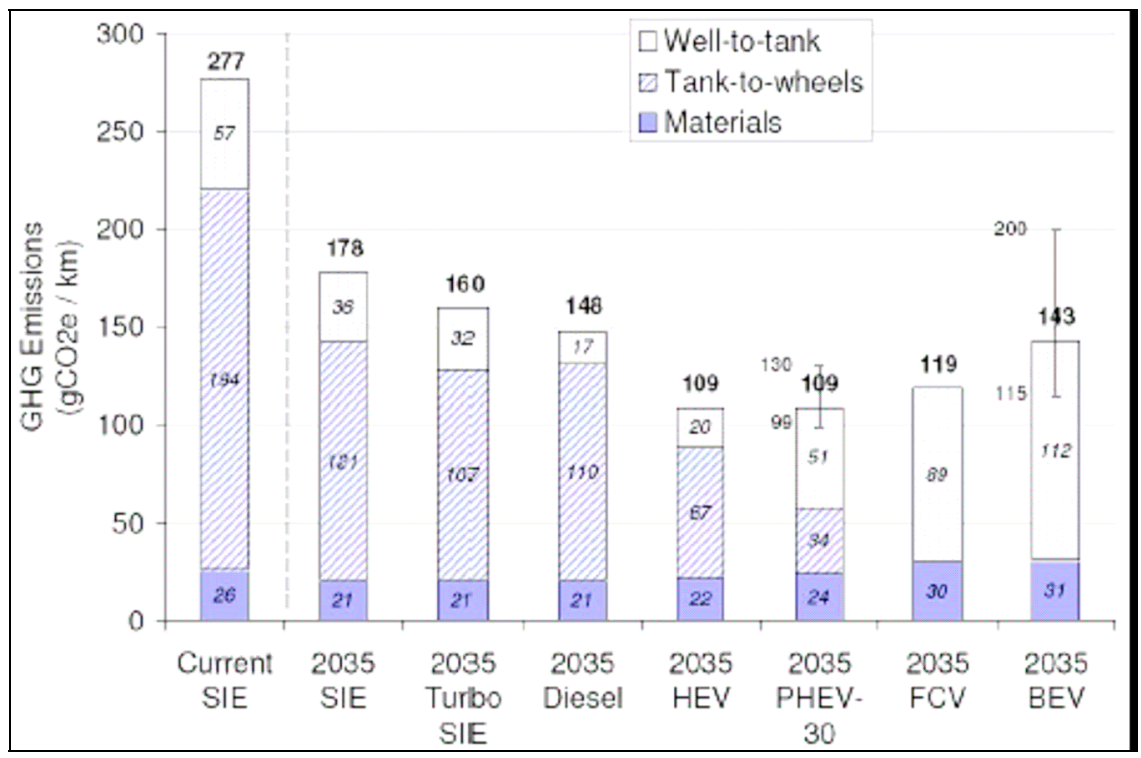

Figure 2: $\quad$ Lifecycle GHG emissions [7].

The study concludes that a $30-50 \%$ reduction in fuel consumption of new light-duty vehicles is feasible over the next $20-30$ years. The greater uncertainty lies with the time necessary to achieve these changes, rather than the technological options available to realize them.

\subsection{The JRC analysis}

The JRC report provides a comprehensive analysis of the vehicle technical improvement options that could be achieved and marketed within 2020, and estimates the size of the environmental improvement potentials related to each option for each stage of the vehicle LC [6].

The technical improvements considered were compared to two reference car models, for gasoline and diesel cars, representative of the new passenger cars fleet in the EU-25 in 2005, averaging the characteristics values from the automotive market data (Table 1). The improvement options were evaluated including technical information from the industry, scientific publications and recent Commission's impact assessments - supporting policy developments. All the directives and proposals of the Commission were considered, regarding the new air pollution standards, for $\mathrm{CO}_{2}$ emissions standards from passenger cars, for a new Directive regarding fuel quality, about vehicle end-of-life targets and the use of biofuels.

The life cycle data for the extraction, processing and production of materials were obtained from the Ecoinvent database and the International Iron and Steel Institute data, while the Energy used (and fuel mix) for the assembly phase was 
Table 1: $\quad$ Main characteristics of the reference vehicles.

\begin{tabular}{|c|c|c|c|}
\hline base case car & unit & Petrol & diesel \\
\hline Average Lifespan & years & 12.5 & 12.5 \\
\hline Emission standard & & EURO4 & EURO4 \\
\hline Average Annual distance & $\mathrm{Km}$ & 16900 & 19100 \\
\hline Average total mileage & $\mathrm{Km}$ & 211250 & 238750 \\
\hline Average Cylinder capacity & $\mathrm{cm}^{3}$ & 1585 & 1905 \\
\hline Average Weight & $\mathrm{Kg}$ & 1240 & 1463 \\
\hline
\end{tabular}

derived from a study published by Volkswagen. The GHG emissions for the TTW phase were estimated using emissions database of real world driving cycles, especially the ARTEMIS database. For the WTW phase the JRC(IES)/CONCAWE/EUCAR study and the Ecoinvent database were considered. In Figure 3 the resulting GHG emissions of some of the improving options are shown for the gasoline and diesel passenger cars.

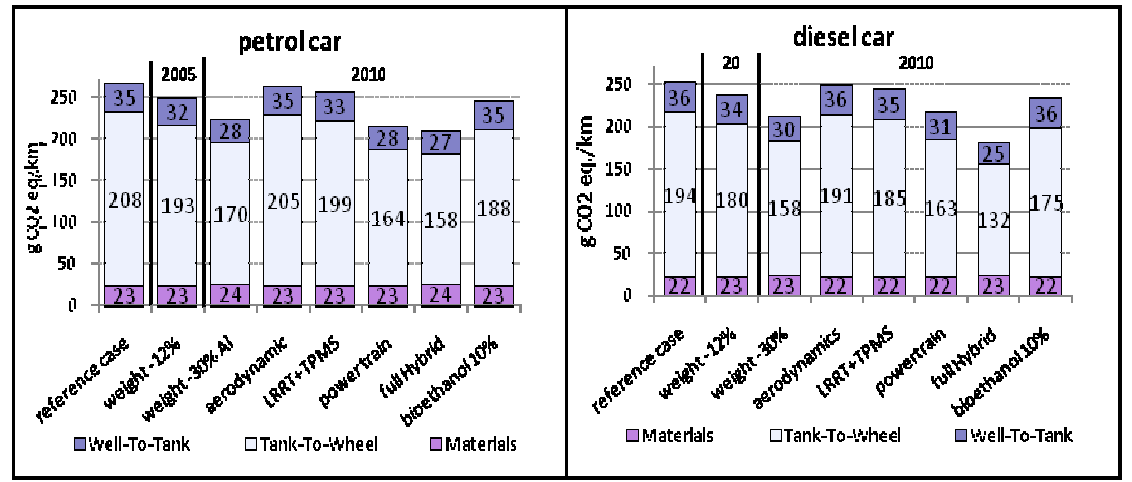

Figure 3: $\quad$ LC GHG emissions for technological options.

\section{Methodology and data description}

The data collected from the studies described in section 2 were utilized to compare two scenarios of different average car lifespan, considering the Italian car fleet characteristics:

- A "Business As Usual" scenario, with the average age of retired cars estimated from National database [8], equal to 12 years (Figure 4);

- An "accelerated scrappage" scenario, with the average age equal to 10 years. It was fixed on the basis of the used cars market data, and it is expected to be economically neutral for a car owner to sell it to a re-user or to scrappage if a $700 €$ public subsidy is forecast in the latter case [9].

The GHG emissions were estimated in a range of 24 years, from 1996 to 2020 , considering 10 car owners, so to have 240 years of total lifespan for the 10 cars fleet, for both the following scenarios: 


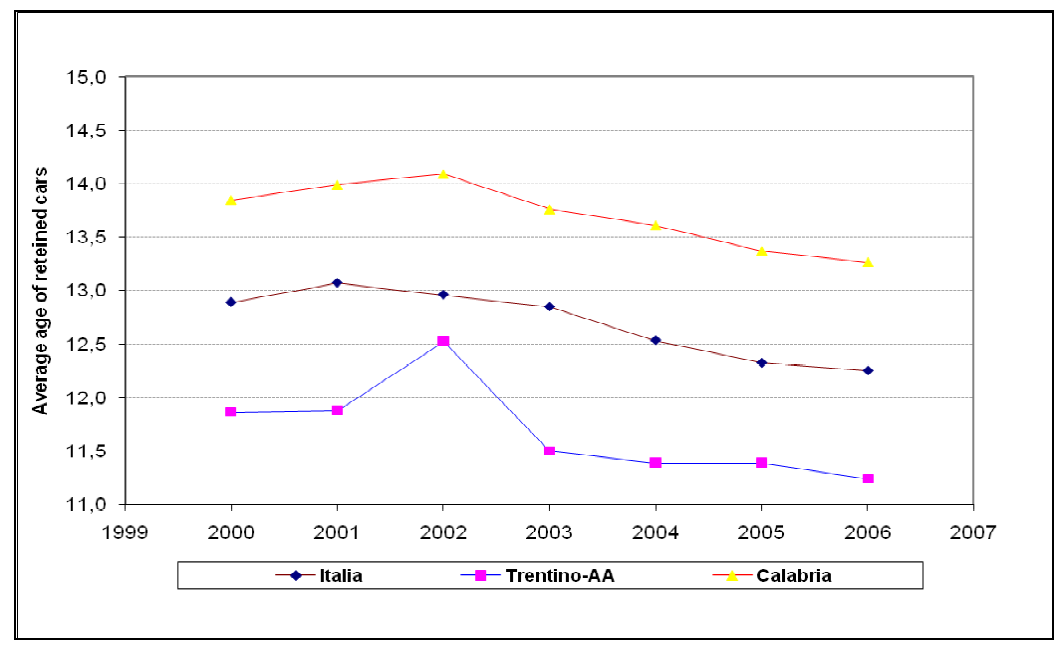

Figure 4: $\quad$ Italian retired cars average age.

- BAU scenario, where all the cars bought in 1996 are replaced after 12 years, first time in 2008;

- "Accelerated scrappage" scenario, where 6 owners continue to replace the car after 12 years, the other four replace the car every 8 years, in 2004 and in 2012. The resulting average car lifespan is 10 years.

Two scenarios of technological improvements were evaluated: a baseline scenario, with a trendy development of the conventional vehicles, and an advanced option, with enhanced hybrid vehicles. North-American cases, based on MIT data, and European cases, based on JRC results, were analyzed. All the emissions were calculated applying the scaling methods for the improvements.

\subsection{American case studies}

The two technological scenarios considered correspond to the 2035 SIE car and the $2035 \mathrm{HEV}$ car (Figure 2). The data used for the GHG emissions calculations of the two scenarios are reported in Table 2.

Table 2: $\quad$ GHG emission for the 3 phases.

\begin{tabular}{|c|c|c|c|c|c|c|}
\hline LC phase & GHG emissions & $\mathbf{1 9 9 6}$ & $\mathbf{2 0 0 4}$ & $\mathbf{2 0 0 8}$ & $\mathbf{2 0 1 2}$ & $\mathbf{2 0 2 0}$ \\
\hline $\begin{array}{c}\text { Materials } \\
\text { GHG metric tons/vei. }\end{array}$ & Baseline & 7,7 & 7,7 & 7,9 & 8,1 & 8,5 \\
\cline { 2 - 7 } & Advanced & 7,7 & 7,7 & 8,1 & 8,5 & 9,3 \\
\hline $\begin{array}{c}\text { WTT } \\
\text { g CO}\end{array}$ eq./km & Baseline & 62 & 57 & 54 & 52 & 46 \\
\cline { 2 - 7 } & Advanced & 62 & 57 & 52 & 47 & 38 \\
\hline $\begin{array}{c}\text { TTW } \\
\text { g CO}\end{array}$ eq./km & Baseline & 210 & 194 & 185 & 175 & 156 \\
\cline { 2 - 7 } & Advanced & 210 & 194 & 180 & 166 & 139 \\
\hline
\end{tabular}




\subsection{JRC case studies}

Three technological scenarios (the baseline one, two advanced) were calculated for both gasoline and diesel cars, considering the ACEA statistics on $\mathrm{CO}_{2}$ emission of sold cars for the 1996, and the TTW $\mathrm{CO}_{2}$ emissions targets proposed by the European Commissions, $120 \mathrm{gCO}_{2} / \mathrm{km}$ as an average of sold cars in 2020 in a softer hypothesis and $95 \mathrm{gCO}_{2} / \mathrm{km}$ in an harder one. To meet those targets a technologies combination was assumed, using data and evaluations of the JRC report (Table 3 ).

The total TTW GHG emissions were established starting from the $\mathrm{CO}_{2}$ emissions, estimating the percentage of $\mathrm{CH}_{4}$ and $\mathrm{N}_{2} \mathrm{O}$ emission through the COPERT 4 emissions for EURO 2 cars (1996) and EURO 4 cars (2004) [10], using the Italian speed and mileage percentages of urban-rural-highways driving

Table 3: $\quad$ Technologies combinations.

\begin{tabular}{|c|c|c|c|c|c|c|}
\hline & \multicolumn{3}{|c|}{ gasoline car } & \multicolumn{3}{|c|}{ diesel car } \\
\hline $\begin{array}{l}\text { TTW } 2005 \\
\text { g CO}_{2} / \mathbf{k m}\end{array}$ & \multicolumn{3}{|c|}{169} & \multicolumn{3}{|c|}{155} \\
\hline $\begin{array}{c}\text { technologies } \\
\text { scenario } \\
\end{array}$ & baseline & advanced & $\begin{array}{c}\text { Adv. } \\
\text { hybrid }\end{array}$ & baseline & advanced & $\begin{array}{c}\text { Adv. } \\
\text { hybrid }\end{array}$ \\
\hline $\begin{array}{c}\text { Target } \\
\mathrm{gCO}_{2} / \mathbf{k m}\end{array}$ & 120 & 95 & $\leq 95$ & 120 & 95 & $\leq 95$ \\
\hline technologies & $\begin{array}{l}\text { Aerody- } \\
\text { namics } \\
\text { tyre } \\
\text { powertrain }\end{array}$ & $\begin{array}{c}\text { weight- } 12 \% \\
\text { aerodyn. } \\
\text { tyre } \\
\text { powertrain }\end{array}$ & $\begin{array}{l}\text { full hybrid } \\
\text { aerodyn. } \\
\text { tyre } \\
\text { powertrain }\end{array}$ & $\begin{array}{l}\text { Aerodyn. } \\
\text { tyre } \\
\text { powertrain }\end{array}$ & $\begin{array}{c}\text { weight- } 12 \% \\
\text { aerodyn. } \\
\text { tyre } \\
\text { powertrain }\end{array}$ & $\begin{array}{l}\text { full hybrid } \\
\text { aerodyn. } \\
\text { tyre } \\
\text { powertrain }\end{array}$ \\
\hline $\begin{array}{c}\text { Em. } \\
\text { Reduction }\end{array}$ & $73 \%$ & $59 \%$ & $49 \%$ & $78 \%$ & $64 \%$ & $47 \%$ \\
\hline $\begin{array}{l}2020 \mathrm{em} . \\
\mathrm{g} \mathrm{CO}_{2} / \mathrm{km}\end{array}$ & 123 & 100 & 83 & 121 & 100 & 72 \\
\hline
\end{tabular}

Table 4: $\quad$ GHG emissions for the 3 phases.

\begin{tabular}{|c|c|c|c|c|c|c|c|c|c|c|c|}
\hline \multicolumn{2}{|c|}{ GHG em. of LC phases } & \multicolumn{5}{|c|}{ gasoline car } & \multicolumn{5}{|c|}{ diesel car } \\
\hline LC phase & $\begin{array}{c}\text { Tecnologies } \\
\text { scenario }\end{array}$ & 96 & '04 & '08 & '12 & '20 & 696 & '04 & ‘08 & '12 & '20 \\
\hline \multirow{3}{*}{$\begin{array}{l}\text { Materials } \\
\mathrm{t} \mathrm{CO}_{2} \text { eq. }\end{array}$} & Baseline & 4,70 & 4,70 & 4,70 & 4,70 & 4,70 & 5,20 & 5,20 & 5,20 & 5,20 & 5,20 \\
\hline & Advanced & 4,70 & 4,70 & 4,70 & 4,70 & 4,70 & 5,20 & 5,20 & 5,20 & 5,20 & 5,20 \\
\hline & Adv. hybrid & 4,70 & 4,70 & 4,76 & 4,82 & 4,94 & 5,20 & 5,20 & 5,27 & 5,33 & 5,46 \\
\hline \multirow{3}{*}{$\begin{array}{c}\text { TTW } \\
\mathrm{g} \mathrm{CO}_{2} \text { eq. } / \mathrm{km}\end{array}$} & Baseline & 189 & 173 & 162 & 150 & 126 & 176 & 158 & 149 & 139 & 121 \\
\hline & Advanced & 189 & 173 & 153 & 134 & 100 & 176 & 158 & 143 & 129 & 100 \\
\hline & Adv. hybrid & 189 & 173 & 149 & 126 & 83 & 176 & 158 & 136 & 115 & 72 \\
\hline \multirow{3}{*}{$\begin{array}{c}\text { WTT } \\
\mathrm{g} \mathrm{CO}_{2} \text { eq. } / \mathrm{km}\end{array}$} & Baseline & 32 & 29 & 27 & 24 & 19 & 30 & 27 & 25 & 22 & 18 \\
\hline & Advanced & 32 & 29 & 25 & 21 & 15 & 30 & 27 & 24 & 21 & 15 \\
\hline & Adv. hybrid & 32 & 29 & 25 & 0 & 12 & 30 & 27 & 22 & 18 & 11 \\
\hline
\end{tabular}


modes. Future vehicles were supposed to have no significant GHG emissions either then $\mathrm{CO}_{2}$. The JRC average total mileages for both petrol and diesel car were used.

The WTT emissions were calculated considering an efficiency improvement from $17 \%$ in 2000 to $15 \%$ in 2020 on the fuel consumed in the fuel cycle, as resulted in the JRC-CONCAWE [11]. The Materials processes emissions were estimated considering the same emissions from 1996 to 2004, and applying the improvement percentages on the future vehicle productions as indicated in the JRC work. The resulting values are shown in Table 4.

\section{Results and conclusions}

Within the hypothesis adopted in this study, both the American and the European accelerated scrappage scenario produce an increase in GHG emissions around $1 \%$, as shown in Table 5 , that can be considered within the calculations errors.

Table 5: $\quad$ GHG emissions for all the case studies.

\begin{tabular}{|c|c|c|c|c|c|c|c|c|}
\hline $\begin{array}{c}\text { case } \\
\text { studies }\end{array}$ & \multicolumn{2}{|c|}{ American } & \multicolumn{2}{c|}{ European petrol car } & \multicolumn{2}{c|}{ European diesel car } \\
\hline $\begin{array}{c}\text { scenario } \\
\text { GHG } \\
\text { t CO }\end{array}$ eq. & baseline & advanced & baseline & advanced & $\begin{array}{c}\text { advanced } \\
\text { hybrid }\end{array}$ & baseline & advanced & $\begin{array}{c}\text { advanced } \\
\text { hybrid }\end{array}$ \\
\hline BAU & 1382 & 1369 & 917 & 903 & 893 & 972 & 957 & 940 \\
\hline $\begin{array}{c}\text { Accelerated } \\
\text { Scrappage }\end{array}$ & 1403 & 1388 & 926 & 910 & 899 & 983 & 966 & 947 \\
\hline $\begin{array}{c}\text { \% GHG } \\
\text { reduction }\end{array}$ & $\mathbf{- 1 , 5 \%}$ & $\mathbf{- 1 , 4 \%}$ & $\mathbf{- 1 , 0 \%}$ & $\mathbf{- 0 , 8 \%}$ & $\mathbf{- 0 , 7 \%}$ & $\mathbf{- 1 , 1 \%}$ & $\mathbf{- 0 , 9 \%}$ & $\mathbf{- 0 , 7 \%}$ \\
\hline
\end{tabular}

The discrepancies between the two case studies are related to the car characteristics and annual mileages: a 2.5-liter engine and $20000 \mathrm{~km} /$ year for the American vehicle, a 1.6-liter engine and $16900 \mathrm{~km} /$ year for the European petrol car. Moreover, the WTT phase for American case is more energy consuming than the European one.

In Figure 5 the detailed emissions for the three LC phases are shown for all the case studies. It results that the reduction in $\mathrm{GHG}$ emissions obtained during vehicles operation is lost with the increase in the vehicle production stage.

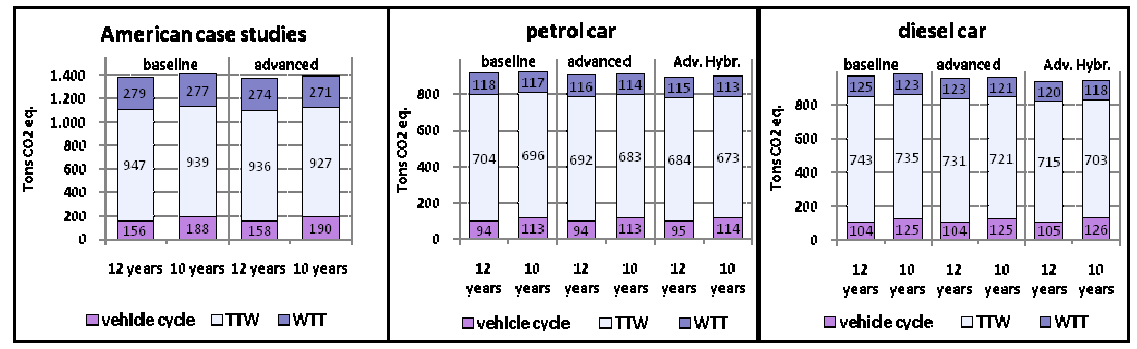

Figure 5: $\quad$ GHG emissions. 
In conclusion, the considered scrappage policy results neutral from the GHG emissions point of view, if targeted to a replacement with conventional cars with more stringent $\mathrm{CO}_{2}$ emissions standard. For technology advanced scenarios, the gaps between BAU and accelerated scrappage are even smaller. Nevertheless, it is to emphasize that this estimation is very cautious, due to the lack of data about the batteries end-of-life and re-use.

Table 6: Technologies impacts for the petrol car [6].

\begin{tabular}{|c|c|c|c|c|c|c|}
\hline $\begin{array}{c}\text { Impacts normalized to a 100 km distance } \\
\text { for petrol car (\%) }\end{array}$ & Reference & Aerodynamics & Tyres & $\begin{array}{c}\text { Power train } \\
\text { improvements }\end{array}$ & $\begin{array}{c}\text { Weight } \\
\text { reduct. } \\
-12 \%\end{array}$ & $\begin{array}{c}\text { Hybrid } \\
\text { car }\end{array}$ \\
\hline abiotic depletion & 100 & 100 & 100 & 100 & 98,4 & 55,1 \\
\hline climate change & 100 & 98,7 & 96 & 80,5 & 93,9 & 78,4 \\
\hline ozone depletion & 100 & 98,6 & 95,9 & 79,7 & 93,7 & 77,2 \\
\hline photochemical oxidation & 100 & 99,1 & 97,3 & 86,6 & 95,7 & 75 \\
\hline acidification & 100 & 99 & 97 & 85,2 & 96,3 & 90,6 \\
\hline eutrophication & 100 & 99,1 & 97,4 & 87,2 & 96,7 & 83,1 \\
\hline 2.5 microns particulate matter & 100 & 98,9 & 96,8 & 84,3 & 100,8 & 88 \\
\hline consumption of primary energy resources & 100 & 98,7 & 96,1 & 80,9 & 94,3 & 78,6 \\
\hline solid waste & 100 & 99,6 & 98,9 & 94,6 & 103,3 & 104,3 \\
\hline Monetarised Aggegated impacts & & 98,5 & 96 & 81,5 & 94,4 & 83,1 \\
\hline
\end{tabular}

Considering also other environmental impacts, as those listed in Table 6, by using the JRC data, the scrappage subsidies are globally efficient, at least so far as improvement in vehicles emission standards are provided thanks to UE legislation (see Table 6 for the petrol car case).

\section{References}

[1] ECMT, Conclusions and recommendations on scrappage schemes and their role in improving the environmental performance of the car fleet CEMT/CM(99)26/FINAL. European Conference of Ministers of Transport, June 1999

[2] Commission of the European Communities, Commission staff working document accompanying the Communication From The Commission - $A$ European Strategic Energy Technology Plan (SET-Plan) - Capacities map, SEC(2007)1511, November 2007

[3] Defra, An Evaluation of the Air Quality Strategy: Local Road Transport Measures - Final Report, ED50232, December 2004

[4] http://lct.jrc.ec.europa.eu/

[5] Michael Spielmann, Paul Scherrer Institute, Hans-Jörg Althaus, Swiss Federal Laboratories for Materials Testing and Research "Can a prolonged use of a passenger car reduce environmental burdens? Life Cycle analysis of Swiss passenger cars", Journal of Cleaner Production 15 (2007), p.11221134, Elsevier 
[6] F. Nemry, G. Leduc, I. Mongelli, A. Uihlein, Environmental Improvement of Passenger Cars (IMPRO-car), JRC 40598, EUR 23038 EN, March 2008

[7] Anup Bandivadekar et al., "On the Road in 2035: Reducing Transportation's Petroleum Consumption and GHG Emissions”, MIT Report No. LFEE 2008-05 RP, July 2008

[8] Automobile Club d'Italia, "Annuario Statistico 2007”, 2008

[9] Quattroruote, Gennaio 2009

[10] http://lat.eng.auth.gr/copert/

[11] Edwards R, Larivé JF, Mahieu V, Rouveirolles P., Well-to-Wheels analysis of future automotive fuels and powertrains in the European context, European Commission DG JRC/IES, CONCAWE and EUCAR, 2006 